\title{
PENGENALAN JENIS SERAGAM LORENG TNI MENGGUNAKAN KOMBINASI ECCENTRICITY DAN METRIC
}

\author{
Hertiana Bethaningtyas $^{1}$, Hasbi Naufal ${ }^{2}$, Gama Wisnu Fajarianto ${ }^{3}$ \\ ${ }^{1,2}$ Fakultas Teknik Elektro, Universitas Telkom \\ ${ }^{3}$ Fakultas Ilmu Komputer, Universitas Jember \\ 1'hertiana@telkomuniversity.ac.id, ${ }^{2}$ hasbinaufalash@gmail.com, ${ }^{3}$ gamawisnuf@unej.ac.id
}

\begin{abstract}
Abstrak
Seragam militer sebagai identitas sebuah negara memiliki ciri khusus warna atau corak tertentu. Identifikasi ciri tersebut dapat dilakukan dengan analisa pengolahan citra digital. Salah satu metode pengenalan seragam militer yang banyak digunakan adalah menggunakan Hue Color Histogram. Namun, metode ini kurang tepat digunakan ketika ada intensitas cahaya terhadap objek yang akan mempengaruhi distribusi nilai warna. Sehingga objek yang berbeda akan terdeskripsi sama akibat memiliki komposisi warna yang sama. Paper ini mengusulkan metode kombinasi eccentricity dan metric dimana kelebihan dari metode ini adalah nilai eccentricity dan metric dari suatu objek tidak akan berubah walaupun posisi objek dilakukan perputaran sudut. Objek citra yang digunakan adalah Jenis Loreng Seragam TNI. Hasil pengujian dari 80 data citra loreng didapat akurasi $87.5 \%$ dan akurasi dengan data citra loreng lain menghasilkan nilai akurasi $\mathbf{9 2 . 1 \%}$ menunjukkan metode yang diusulkan kompetitif.
\end{abstract}

Kata Kunci: Segmentasi, Eccentricity, Metric

\section{Abstract}

Military uniforms as the identity of a country have special features of certain colors or patterns. Identification of these characteristics can be done with digital image processing analysis. One of the military uniform recognition method using Hue Color Histogram. The Hue Color Histogram method is less precisely used when there is light intensity against the object that will affect the distribution of color values. So that different objects will be the same descriptions due to having the same color composition. In this paper proposes a combination method of eccentricity and metrics where the advantages of this method are the value of eccentricity and metrics of an object will not change even though the position of the object is rotated angle. The image used is Loreng TNI uniform. The test results from 80 loreng image data obtained $87.5 \%$ accuracy and accuracy with other image data results accuracy $92.1 \%$ indicating the competitiveness of this method.

\section{Keywords: Segmentation, Eccentricity, Metric}

\section{Pendahuluan}

Seragam militer memiliki ciri khusus warna atau corak bentuk tertentu sebagai identitas sebuah negara. Ciri khusus tersebut digunakan dengan salah satu tujuan sebagai identifikasi dalam pertempuran untuk mengenali pemakai sebagai salah satu anggota militer[1]. Identifikasi ciri pada seragam militer dapat dilakukan dengan analisa pengolahan sinyal objek citra dijital. Pengenalan objek citra dapat berupa identifikasi warna atau bentuk. Salah satu metode pengenalan seragam militer yang banyak digunakan adalah menggunakan Hue Color Histogram.

Penelitian tersebut menggunakan metode Hue Color Histogram. Hue Color Histogram merupakan metode pengolahan citra dijital untuk mendapatkan distribusi nilai warna dari sebuah objek citra [2]. Kekurangan metode Hue Color Histogram adalah intensitas cahaya terhadap objek sangat mempengaruhi distribusi nilai warna. Sehingga objek yang berbeda akan terdeskripsi sama akibat memiliki komposisi warna yang sama.

Untuk mengatasi kendala pengaruh intensitas cahaya, pada penelitian ini dilakukan identifikasi seragam militer menggunakan analisa bentuk dengan metode pengenalan pola bentuk. Pengenalan pola bentuk merupakan metode yang meggunakan dua kombinasi parameter yaitu eccentricity dan metric dari suatu objek pada citra biner. Keunggulan dari metode ini adalah nilai eccentricity dan metric dari suatu objek tidak akan berubah walaupun posisi objek dilakukan perputaran sudut [3]. Tahapan penelitian berupa proses segmentasi citra RGB, citra grayscale, contrast adjustment, serta proses perhitungan eccentricity dan metric pada citra biner. Objek citra yang digunakan pada penelitian adalah Jenis Loreng Seragam TNI 'Malvinas' dengan 4 tipe bentuk yang dipilih. Dimana hasil dari identifikasi menggunakan metode pola bentuk akan dibandingkan dengan metode Hue Color Histogram. 


\section{Citra dan Pengenalan Pola}

Citra atau gambar merupakan fungsi dalam bentuk dua dimensi $f(x, y)$, dimana $x$ dan y adalah koordinat spasial (bidang), dan amplitudo fungsi $\mathrm{f}$ dari setiap koordinat bidang menunjukan tingkat intesitas cahaya (brightness) pada saat itu [4]. Citra dapat dikategorikan menjadi 2 yaitu citra kontinu dan citra diskrit. Citra kontinyu dihasilkan dari sistem optik (mata atau kamera analog) yang menerima pantulan sinyal analog dari objek seperti pada Gambar 1.

Citra diskrit (citra digital) merupakan citra kontinyu $\mathrm{f}(\mathrm{x}, \mathrm{y})$ yang telah dilakukan diskritisasi atau dijitalisasi sampling dan kuantisasi. Sampling dinyatakan dengan jumlah kotak-kotak (koordinat) baris dan kolom, sementara kuantisasi menyatakan besarnya nilai tingkat kecerahan (brightness level) yang ditunjukan pada Gambar 2.

Dalam citra digital terdapat beberapa elemen penting yaitu: Kecerahan (brightness), kontras (contrast), warna (color), bentuk (shape), dan tekstur (texture). Kecerahan (brightness) merupakan intensitas cahaya yang dipancarkan sebuah titik (piksel) dari citra yang dapat tertangkap oleh sistem optic [5]. Kontras adalah penyebaran gelap dan terang dalam sebuah citra. Citra dikatakan mempunyai kontras yang baik apabila penyebaran terang dan gelapnya merata [5].

Keadaan yang ditimbulkan oleh perubahan intensitas pada piksel-piksel yang bertetanggaan disebut dengan kontur. Sedangkan warna merupakan persepsi yang ditangkap sistem visual manusia terhadap panjang gelombang cahaya yang dipantulkan oleh objek, dimana setiap warna mempunyai panjang gelombang yang berbeda. Elemen berikutnya adalah elemen bentuk. Bentuk merupakan properti intrinsic dari objek 3 dimensi yang tertangkap oleh sistem visual manusia [5]. Elemen yang terakhir adalah elemen tekstur. Tekstur merupakan keteraturan pola-pola tertentu yang terbentuk dari susunan piksel-piksel dalam citra digital. Informasi tekstur dapat digunakan untuk membedakan sifat-sifat permukaan suatu objek dalam citra yang sama sekali terlepas dari warna permukaan objek tersebut [5].

Informasi nilai pada elemen-elemen citra dijital, digunakan untuk melakukan melakukan identifikasi. Salah satu metode identifikasi yang dapat dilakukan adalah proses pengenalan pola. Pengenalan pola adalah mengelompokan data numerik citra secara otomatis oleh mesin (komputer). Pengelompokan ini bertujuan untuk mengenali suatu objek di dalam citra yang dapat membedakan suatu objek dengan objek lain [6].

\subsection{Citra RGB (Red Green Blue)}

Citra RGB (Red Green Blue) merupakan citra true color yang disimpan dalam array berukuran $\mathrm{m} \mathrm{x}$ n x 3 yang mendefinisikan warna merah, hijau, dan biru pada setiap pikselnya. Warna pada setiap piksel merupakan kombinasi dari warna merah, hijau, dan biru sehingga membentuk suatu susunan warna yang luas. Setiap komponen warna diberi nilai antara 0 dan 255 berdasarkan pada 8-digit bilangan biner yang digunakan oleh mesin (komputer). Sebuah warna dapat dianalogikan sebagai sebuah vektor di ruang 3 dimensi yang koordinatnya dinyatakan dalam bentuk tiga bilangan, yaitu komponen $\mathrm{x}$ untuk warna merah (R), komponen y untuk warna hijau (G), dan komponen $\mathrm{z}$ untuk warna biru (B) [4] yang terilustrasikan pada Gambar 3.

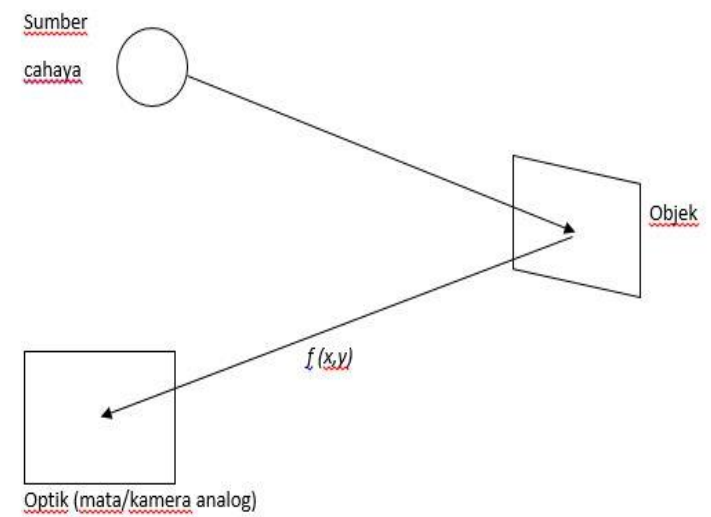

Gambar 1. Proses Pembentukan Citra Kontinu

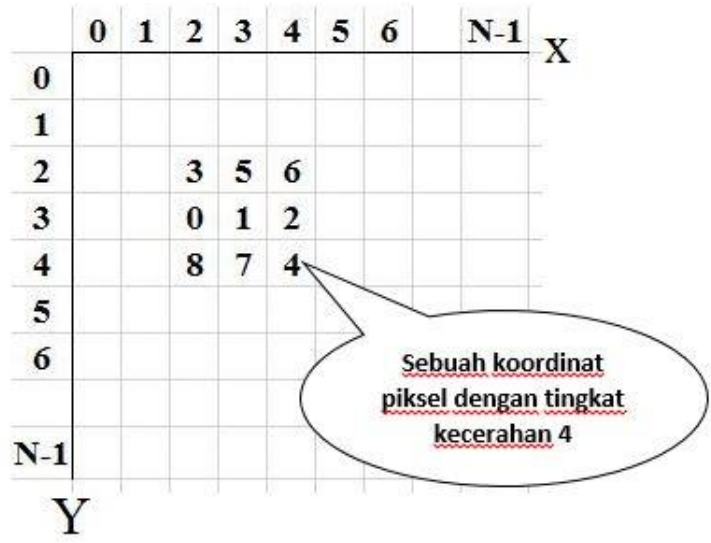

Gambar 2. Koordinat dan Nilai Tingkat Kecerahan Pada Citra Digital

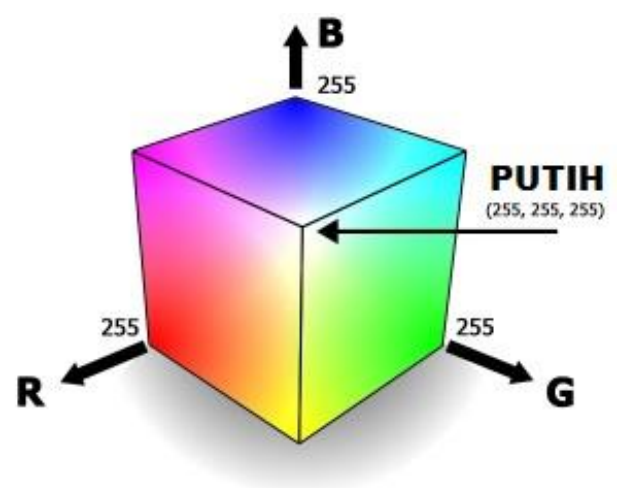

Gambar 3. Ruang Warna RGB Jurnal Penelitian dan Pengembangan Telekomunikasi, Kendali, Komputer, Elektrik, dan Elektronika (TEKTRIKA) Juli 2017 - Volume 2, Nomor 2 


\subsection{Citra HSV (Hue Saturation Value)}

Citra model HSV (Hue Saturation Value) merupakan sistem yang menggabungkan informasi data, baik warna maupun grayscale dari sebuah citra. HSV terdiri dari 3 komponen, yaitu komponen hue saturation, dan value yang terlihat pada gambar 4. Hue mendeskripsikan jenis warna murni yang dianalogikan sebagai sudut $(\theta)$ yang dimulai dari $0^{\circ}$ adalah merah, $60^{\circ}$ adalah kuning, $120^{\circ}$ adalah hijau, $180^{\circ}$ warna cyan, $240^{\circ}$ adalah biru, dan $300^{\circ}$ adalah magenta. Saturasi (saturation)(S) mendeskripsikan tingkat kemurnian suatu warna dengan nilai skala 0-1 (0-100\%). Value $(\mathrm{V})$ dapat disebut juga intensitas yaitu ukuran tingkat kecerahan dari suatu warna atau tingkat intensitas cahaya datang dari suatu warna dengan nilai skala 0-1 (0-100\%) [4][7].

Konversi warna HSV dapat diperoleh dari model RGB dengan persamaan berikut.

$$
H= \begin{cases}\theta & , \text { Jika B } \leq \mathrm{G} \\ 360-\theta & , \text { Jika B }>\mathrm{G}\end{cases}
$$

dengan

$$
\begin{gathered}
\theta=\cos ^{-1}\left\{\begin{array}{l}
\frac{1}{2}[(R-G)+(R-B)] \\
{\left[\begin{array}{l}
(R-G)^{2} \\
+(R-B)(G-B)
\end{array}\right]^{1 / 2}}
\end{array}\right\} \theta \\
\theta=\cos ^{-1}\left\{\begin{array}{l}
\frac{1}{2}[(R-G)+(R-B)] \\
{\left[\begin{array}{l}
(R-G)^{2} \\
+(R-B)(G-B)]
\end{array}\right]}
\end{array}\right\} \\
S=1-\frac{3}{(R+G+B)}[\min (R, G, B)] S \\
S=1-\frac{V}{(R+G+B)}[\min (R, G, B)] \\
V=\frac{1}{3}(R+G+B) V \\
\frac{1}{3}(R+G+B)
\end{gathered}
$$

Konversi pada persamaan (1), (2), (3), dan (4) dilakukan dengan kondisi warna RGB telah dinormalisasi dalam rentang $[0,1]$ dan sudut $\theta$ diukur dari sumbu merah (red). Hue dinormalisasi menjadi $[0,1]$ dengan cara membaginya dengan sudut $360^{\circ}$ [4]. Normalisasi warna RGB dapat dilakukan dengan membagi nilai RGB dengan 255.

\subsection{Citra Grayscale}

Grayscale adalah sebuah teknik mengubah gambar atau citra berwarna (RGB) menjadi citra berwarna abu-abu. Untuk mengubah menjadi citra grayscale ketiga kompenen RGB harus dijumlahkan dan dibagi 3, sehingga menjadi 1 komponen yang menyimpan nilai piksel antara 0 (warna hitam) sampai dengan 255 (warna putih), sedangkan untuk nilai diantara 0-255 adalah warna abu-abu. Secara matematis konversi citra RGB menjadi citra grayscale ditunjukan dalam persamaan berikut [4]

$$
\begin{aligned}
& \text { Grayscale }=\frac{(R+G+B)}{3} M S E \\
& \text { Grayscale }=\frac{1}{n} \sum_{i=1}^{n}\left(S_{e}-S\right)^{2} \\
& \text { Grayscale }=\frac{(R+G+B)}{3}
\end{aligned}
$$

\subsection{Citra Biner (black \& white)}

Citra biner (black and white) merupakan citra yang hanya memiliki dua nilai derajat keabuan: hitam dengan nilai 0 dan putih dengan nilai 1 . Sehingga setiap piksel pada citra biner cukup direpresentasikan dengan 1 bit. Untuk mendapatkan format citra biner dapat dilakukan proses binarization, yaitu memisahkan piksel yang ada pada citra menjadi hanya dua jenis piksel yaitu hitam dan putih menggunakan persamaan berikut [8]

$$
\tau \theta(x)= \begin{cases}0 & , 0 \leq x \leq \theta \\ 1 & , x>\theta\end{cases}
$$

Nilai $\mathrm{x}$ adalah nilai intensitas pada citra yang akan dibandingkan dengan nilai threshold $(\theta)$.

Apabila nilai intensitas ( $\mathrm{x}$ ) kurang dari sama dengan nilai threshold $(\theta)$, maka nilai intensitas $(\mathrm{x})$ akan menjadi 0. Sedangkan apabila nilai intensitas (x) lebih besar dari nilai threshold $(\theta)$, maka nilai intensitas (x) akan menjadi 1 dalam skala format citra biner. Untuk mendapatkan nilai threshold $(\theta)$ digunakan metode Otsu, yaitu metode untuk melakukan seleksi nilai threshold dari histogram citra grayscale dengan analisis diskriminan untuk melakukan evaluasi threshold dan memilih nilai optimum secara otomatis [8].

\subsection{Contrast Adjustment}

Sebuah citra dikatakan baik apabila tingkat kecerahan dan kontras proposional. Contrast Adjustment merupakan salah metode perbaikan kualitas citra, yang melakukan penyesuaian nilai intesitas pada setiap piksel dalam sebuah citra. Contrast adjustment sangat membantu untuk mendapatkan pola bentuk dalam sebuah citra, karena akan mempertegas setiap batas yang dihasilkan oleh perbedaan nilai intensitas [9].

\subsection{Eccentricity dan Metric}

Pada pengenalan pola bentuk, terdapat 2 komponen yaitu eccentricity dan metric dengan ilustrasi pada gambar 5. Eccentricity (e) adalah nilai perbandingan antara jarak foci ellips minor (b) dengan foci ellips mayor (a) dari suatu wilayah/bentuk pada objek yang tertulis pada persamaan 7 . 
Nilai eccentricity berada dalam rentang skala 0 sampai 1. Suatu wilayah yang berbentuk memanjang (mendekati garis lurus), maka nilai eccentricity akan mendekati 1, sedangkan wilayah yang berbentuk lingkaran, nilai eccentricity akan mendekati 0. Metric (M) adalah perbandingan antara luas (L) dengan keliling (k) dari wilayah suatu objek [3]. Penghitungan nilai metric terlihat pada persamaan 8 .

$$
\begin{gathered}
e=\sqrt{1-\frac{b^{2}}{a^{2}}} e=\sqrt{1-\frac{b^{2}}{a^{2}}} \\
M S E=\frac{1}{n} \sum_{i=1}^{n}\left(S_{e}-S\right)^{2} \\
M=\frac{4 \pi \cdot L}{K^{2}}
\end{gathered}
$$

\section{Metode Penelitian}

Terdapat beberapa tahapan proses dalam penelitian yang dilakukan, yaitu tahap akuisisi citra dan ekstraksi ciri berupa pengenalan warna dan bentuk. Pada penelitian yang dilakukan, perangkat keras yang digunakan untuk membuat sistem adalah kamera Nikon D3200 AF-S 18-55mm sebagai alat yang digunakan untuk pengambilan data/citra.

Akuisisi citra dilakukan dengan mengkondisikan pengambilan data citra sebagai berikut: jarak terhadap objek adakah 1 meter, dengan mode pengambilan gambar manual tanpa melakukan pembesaran (zooming), dan intensitas cahaya yang digunakan saat pengambilan data citra di atas 800 lux. Intensitas cahaya terhadap objek diukur dengan menggunakan DIGITAL INSTRUMEN LUTRON SL-4112P. Citra yang diperoleh tersimpan sdalam format JPEG dengan dimensi citra 4000x6016.

Data citra yang telah terkumpul akan dilakukan proses ekstraksi ciri. Proses ekstraksi ciri bertujuan untuk mendapatkan informasi dari citra yang akan digunakan sebagai parameter klasifikasi. Metode yang digunakan untuk melakukan proses ekstraksi ciri yaitu menggunakan pola warna dan pola bentuk.

\subsection{Ekstraksi Ciri Pola Warna}

Data citra yang telah terkumpul akan dilakukan proses ekstraksi ciri. Proses ekstraksi ciri bertujuan untuk mendapatkan informasi dari citra yang akan digunakan sebagai parameter klasifikasi.

Informasi citra berupa nilai dari setiap piksel citra. Nilai piksel citra yang dicari adalah nilai penyebaran/rata-rata hue color. Data citra hasil preprocessing tersimpan dalam citra dengan format RGB (Red Green Blue) selanjutnya diproses ke dalam format HSV (Hue Saturation Value).

Citra RGB memiliki 3 komponen red, green, dan blue dengan nilai piksel antara 0-255 harus dinormalisasi dalam nilai antara 0-1. Proses mengubah format citra RGB menjadi HSV ditunjukan pada Gambar 6.

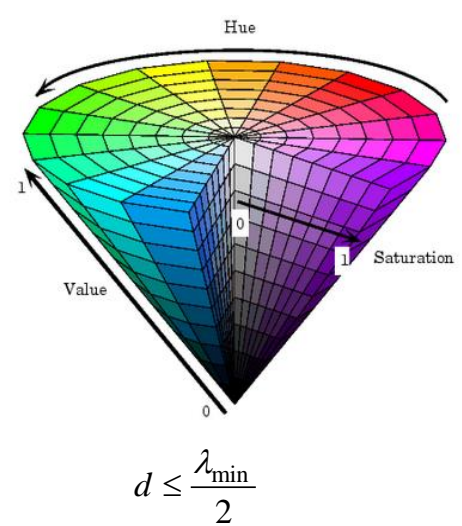

Gambar 4. HSV Color Map [4]

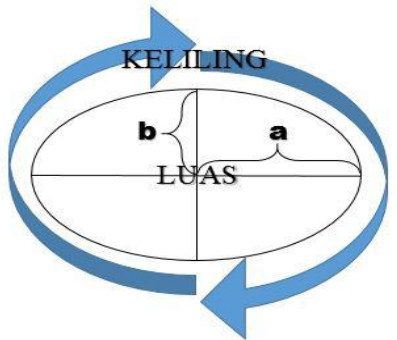

\section{Gambar 5. Ilustrasi Penghitungan Nilai Eccentricity dan Metric}

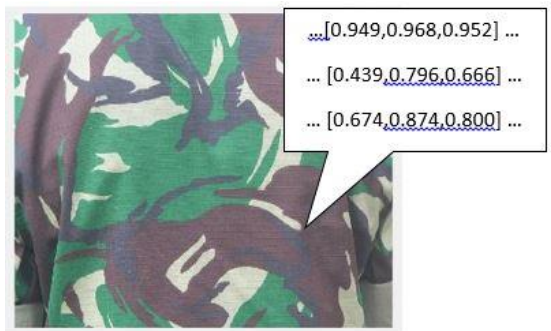

(a)

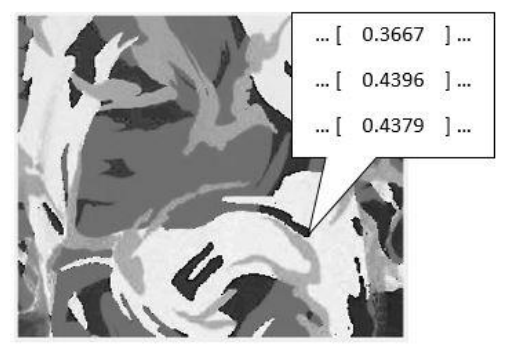

(b)

Gambar 6. Citra RGB Normalisasi (a), dan Citra Hue Color (b)

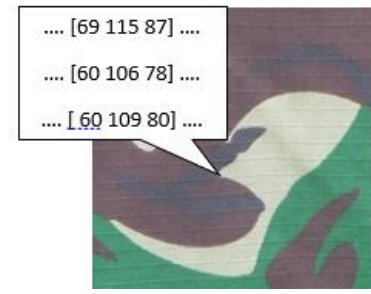

(a)

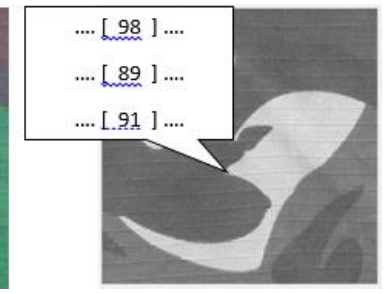

(b)
Gambar 7 (a) Citra RGB dan (b) Citra Grayscale

Jurnal Penelitian dan Pengembangan Telekomunikasi, Kendali, Komputer, Elektrik, dan Elektronika (TEKTRIKA)

Juli 2017 - Volume 2, Nomor 2 


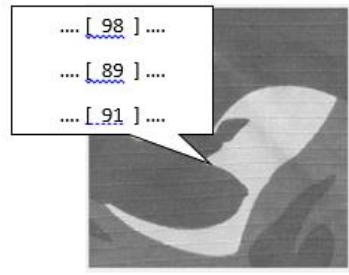

(a)

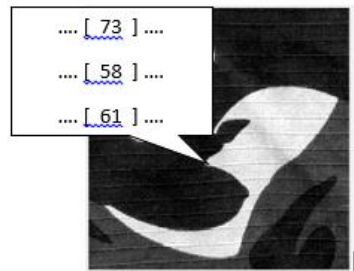

(b)
Gambar 8 Contrast Adjustment: (a) Sebelum dan (b) Setelah

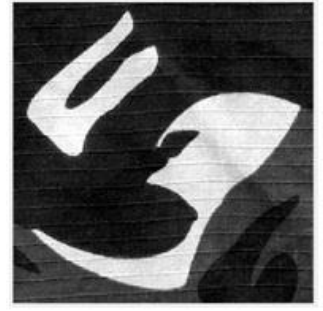

(a)

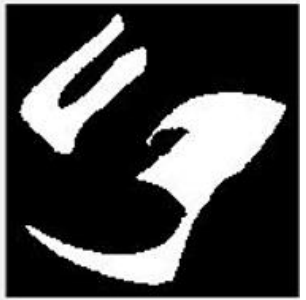

(b)
Gambar 9. (a) Citra Grayscale dengan Contrast Adjustment dan (b) Citra Biner (Black\&White)

\section{Ekstraksi Ciri Pola Bentuk}

Pada tahap ekstraksi ciri data citra yang telah terkumpul akan dilakukan proses segmentasi. Proses segmentasi dilakukan dengan mengelompokan piksel-piksel objek agar menjadi wilayah (region) yang merepresentasikan objek tersebut. Selanjutnya, dilakukan pengolahan data untuk mendapatkan parameter pola bentuk dari objek.

Data yang digunakan dalam pengolahan citra sebanyak 200 data citra loreng "Malvinas". Data tersebut selanjutnya diproses dalam tahapan segmentasi. Dalam proses segmentasi untuk mendapatkan pola bentuk yang merepresentasikan objek, dilakukan tahapan pengolahan data menjadi citra grayscale, contrast adjustment, kemudian menjadi citra biner.

Citra hasil pre-processing yang tersimpan dalam format RGB (Red Green Blue) selanjutnya diubah ke dalam format grayscale dengan cara membagi 3 hasil penjumlahan komponen red, green, dan blue. Dimana proses hasil perubahan terlihat pada gambar7.Sebelum diubah ke dalam bentuk citra biner (citra black\&white), dilakukan proses contrast adjustment pada citra grayscale. Contrast adjustment bertujuan untuk menegaskan setiap batas (boundary) setiap wilayah derajat keabuan, dengan cara meningkatkan nilai intensitas keabuan wilayah terang (putih) dan mengurangi nilai intensitas keabuan wilayah gelap (hitam). Proses contrast adjustment ditunjukan dalam Gambar 8.

Untuk mendapatkan citra biner, terlebih dahulu ditentukan nilai threshold $T$ dan dilakukan pengujian pada setiap piksel dalam citra. Jika nilai intensitas keabuan piksel kurang dari atau sama dengan nilai threshold maka nilai intesitas menjadi 0 , sedangkan untuk nilai intensitas keabuan yang lebih dari nilai threshold maka nilai intensitas menjadi 1 dalam skala format citra biner (black \& white) yang ditunjukan dalam Gambar 9.

Tahapan proses berikutnya adalah perhitungan nilai eccentricity dan metric. Ditentukan titik start point dan new point untuk mendapatkan data titik tepi pada data citra biner dengan background hitam dan putih sebagai warna objek untuk mendapatkan jumlah objek pada citra. Piksel pertama yang memiliki intensitas 1 (putih) akan dijadikan sebagai start point dan diberi label sebagai piksel tepi. Piksel yang berada dikanan, atas, kiri dan bawah piksel star tpoint akan bergeser secara berurutan untuk mendapatkan piksel pertama yang memiliki intensitas 1 (putih). Piksel tersebut akan dijadikan newpoint dan diberi label piksel tepi. Hal ini akan terus berulang sampai new point bertemu dengan start point dan setiap piksel tepi tadi akan terhubung menjadi garis tepi/batas pada objek dengan ilustrasi seperti gambar 10. Piksel tepi yang memiliki koordinat terkecil sumbu $\mathrm{x}$ atau sumbu y dijadikan sebagai titik pertama dan piksel koordinat terbesar sumbu $\mathrm{x}$ atau sumbu $\mathrm{y}$ sebagai titik kedua.
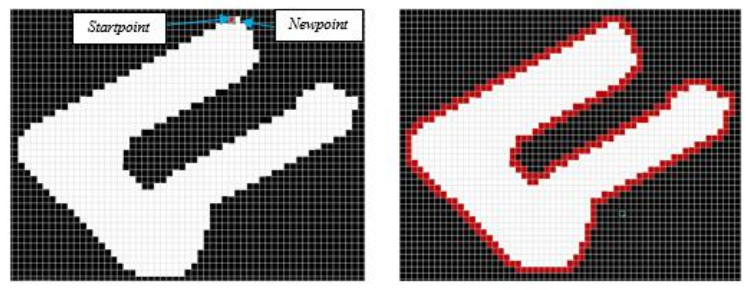

Gambar 10. Ilustrasi Penentuan Startpoint (kiri) dan deteksi tepi (kanan)

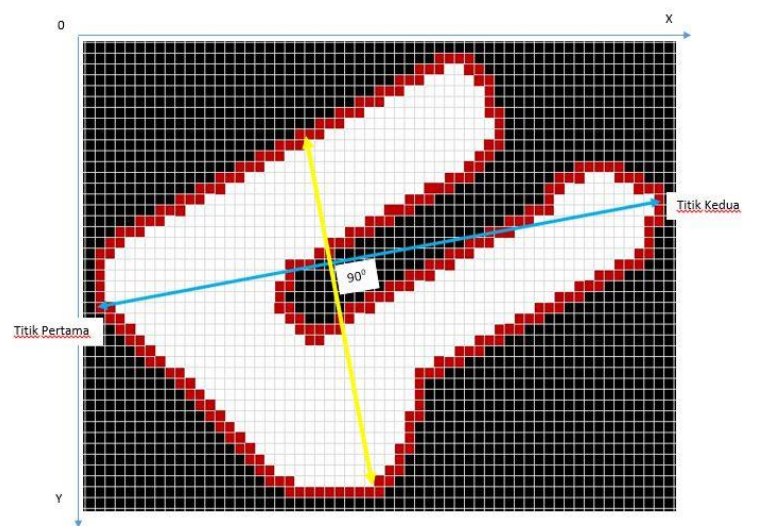

Gambar 11. Majoraxis (Garis Penghubung Titik pertama dan kedua) dan Minoraxis

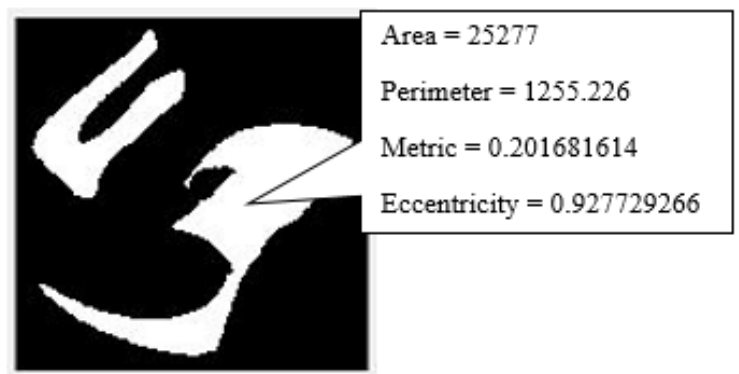

Gambar 12. Parameter Identifikasi Pola Bentuk 
Jarak piksel terbesar dari titik pertama sampai titik kedua akan menjadi major axis pada objek. Minor axis objek didapatkan dengan mencari kombinasi dua piksel tepi yang memiliki jarak piksel terbesar dan harus memotong major axis tegak lurus (sudut $90^{\circ}$ ). Dimana penentuan posisi majo raxis dan minor axis terlihat pada gambar 11. Jumlah piksel yang memiliki intensitas 1 (putih) merupakan luas objek, semetara jumlah piksel tepi/batas objek merupakan keliling objek. Parameter eccentricity dan metric didapatkan dengan memasukan nilai major axis, minor axis, luas dan keliling objek pada persamaan (13 dan 14) dengan keseluruhan data seperti pada gambar 12 .

Tabel 1. Hasil Pengujian Data Latih dan Data Uji Berdasarkan Ekstraksi Ciri Warna

\begin{tabular}{|c|c|c|c|}
\hline Nilai & $\begin{array}{c}\text { Data latih } \\
\text { (Presentase Hue } \\
\text { Color) }\end{array}$ & $\begin{array}{c}\text { Data Uji Benar } \\
\text { (Persentase Hue } \\
\text { Color) }\end{array}$ & $\begin{array}{c}\text { Data Uji Salah } \\
\text { (Persentase Hue } \\
\text { Color) }\end{array}$ \\
\hline $\begin{array}{c}\text { Minimum Hue } \\
\text { Color }\end{array}$ & 0.1289 & 0.1467 & 0.0925 \\
\hline $\begin{array}{c}\text { Maximum Hue } \\
\text { Color }\end{array}$ & 0.6969 & 0.6540 & 0.5923 \\
\hline $\begin{array}{c}\text { Rata-rata Hue } \\
\text { Color }\end{array}$ & 0.2714 & 0.3269 & 0.2816 \\
\hline $\begin{array}{c}\text { Standar } \\
\text { Deviasi Hue } \\
\text { Color }\end{array}$ & 0.2284 & 0.2335 & 0.1193 \\
\hline $\begin{array}{c}\text { Variansi Hue } \\
\text { Color }\end{array}$ & 0.0559 & 0.0592 & 0.0260 \\
\hline
\end{tabular}

Tabel 2 Hasil Pengujian Data Menggunakan Ekstraksi Ciri Warna

\begin{tabular}{|c|c|c|c|c|c|c|}
\hline $\begin{array}{c}\text { Jenis } \\
\text { Data } \\
\text { Citra }\end{array}$ & $\begin{array}{c}\text { Loreng } \\
\text { Malvinas }\end{array}$ & $\begin{array}{c}\text { Loreng } \\
\text { Lain }\end{array}$ & $\begin{array}{c}\text { Error } \\
\text { Malvinas }\end{array}$ & $\begin{array}{c}\text { Error } \\
\text { Loreng } \\
\text { Lain }\end{array}$ & $\begin{array}{c}\text { Akurasi } \\
\text { Loreng } \\
\text { Malvinas }\end{array}$ & $\begin{array}{c}\text { Akurasi } \\
\text { Loreng } \\
\text { Lain }\end{array}$ \\
\hline $\begin{array}{c}\text { Malvinas } \\
\text { Pola } \\
\text { Warna }\end{array}$ & 80 & 35 & 6 & 28 & $92.5 \%$ & $20 \%$ \\
\hline
\end{tabular}

Tabel 3 Proses Segmentasi Pengenalan Pola Bentuk

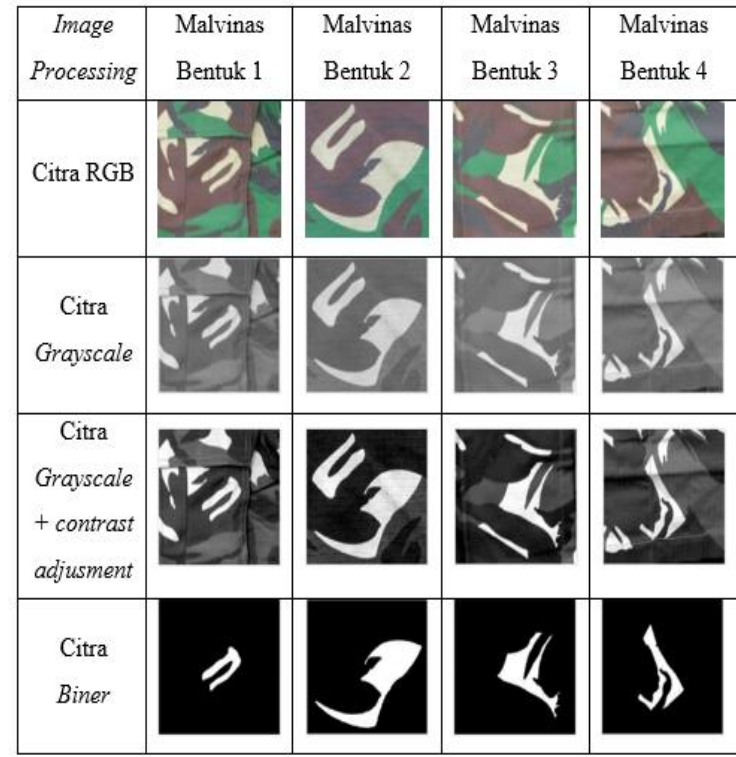

5. Hasil Pengujian dan Pembahasan

Pengumpulan data penelitian dilakukan dengan mengambil citra Tentara Nasional Indonesia (TNI) yang menggunakan pakaian dinas lapangan (PDL) berupa loreng Malvinas secara langsung. Selain itu data citra dapat diambil dari bahan dasar kain untuk membuat PDL. Untuk keperluan pengenalan pola bentuk data yang terkumpul akan dilakukan pemotongan (cropping) dengan ukuran /resolusi citra yang sama pada bagian-bagian tertentu.

\subsection{Pengujian Berdasarkan Ekstraksi Ciri Pola Warna}

Proses pelatihan sistem menggunakan 200 data citra latih loreng Malvinas. Pengujian sistem dilakukan dengan menggunakan 80 data citra uji loreng malvinas dan 35 data citra uji loreng lain. Dalam pengolahan data, Citra RGB diubah menjadi citra HSV agar mendapatkan komponen persentase hue color (dengan skala 0-1). Nilai penyebaran komponen hue color menjadi parameter utama dalam pengujian berdasarkan ciri pola warna. Hasil pengujian data latih dan hasil pengujian ekstraksi citra warna dapat dilihat pada tabel 1 dan 2 . Berdasarkan hasil pengujian, pada tabel 2, dari 80 citra uji loreng malvinas terdapat 6 error data citra loreng malvinas yang tidak dapat teridentifikasi. Sehingga menghasilkan akurasi sebesar $92.5 \%$. Pengujian juga dilakukan dengan menggunakan jenis loreng lain, terdapat 28 citra loreng lain yang teridentifikasi sebagai jenis loreng malvinas. Sehingga akurasi yang dihasilkan pada pengujian ini sebesar 20\%. $80 \%$ data error pada pengujian menggunakan jenis loreng lain menunjukan bahwa ekstraksi ciri warna tidak dapat membedakan jenis loreng malvinas dengan loreng lain, karena hanya menggunakan penyebaran warna hue sebagai parameter.

Jurnal Penelitian dan Pengembangan Telekomunikasi, Kendali, Komputer, Elektrik, dan Elektronika (TEKTRIKA)

Juli 2017 - Volume 2, Nomor 2 


\section{Pengujian Berdasarkan Ekstraksi Ciri Pola Bentuk}

Untuk mendapatkan parameter pola bentuk dilakukan beberapa proses segmentasi yaitu grayscale (mengubah citra RGB menjadi citra abuabu), contrast adjustment (meningkatkan kontras citra dengan menambah dan mengurangi tingkat keabuan pada citra abu-abu), binarization (mengubah citra abu-abu dengan penambahan kontras menjadi citra hitam dan putih), dan labelling (pemberian identitas/penomoran setiap bentuk yang tercipta pada citra hitam dan putih). Hasil dari proses segmentasi adalah citra biner (hitam dan putih) yang telah dilakukan labelling pada setiap bentuk yang diperoleh pada data tabel 3. Proses data latih menggunakan 200 data citra loreng malvinas, setiap pola menggunakan masing-masing 50 data citra. Citra biner (hitam dan putih) hasil dari proses segmentasi

Tabel 4. Hasil Pengujian Data Latih Citra Berdasarkan Ekstraksi Ciri Bentuk

\begin{tabular}{|c|c|c|c|c|}
\hline Nilai & $\begin{array}{c}\text { Malvinas } \\
\text { Bentuk 1 }\end{array}$ & $\begin{array}{c}\text { Malvinas } \\
\text { Bentuk 2 }\end{array}$ & $\begin{array}{c}\text { Malvinas } \\
\text { Bentuk 3 }\end{array}$ & $\begin{array}{c}\text { Malvinas } \\
\text { Bentuk 4 }\end{array}$ \\
\hline $\begin{array}{c}\text { Average } \\
\text { Eccentricity }\end{array}$ & 0.873 & 0.930 & 0.762 & 0.924 \\
\hline $\begin{array}{c}\text { Maximum } \\
\text { Eccentricity }\end{array}$ & 0.889 & 0.950 & 0.815 & 0.949 \\
\hline $\begin{array}{c}\text { Minimum } \\
\text { Eccentricity }\end{array}$ & 0.855 & 0.901 & 0.710 & 0.890 \\
\hline Average Metric & 0.238 & 0.207 & 0.135 & 0.121 \\
\hline Maximum Metric & 0.271 & 0.246 & 0.154 & 0.149 \\
\hline Minimum Metric & 0.210 & 0.185 & 0.126 & 0.108 \\
\hline
\end{tabular}

Tabel 2 Contoh Data Citra Loreng Lain dan Hasil Pengolahannya

\begin{tabular}{|c|c|c|c|c|}
\hline $\begin{array}{c}\text { Image } \\
\text { Processing }\end{array}$ & $\begin{array}{c}\text { Loreng } \\
\text { Kopassus }\end{array}$ & $\begin{array}{c}\text { Loreng } \\
\text { Unifil }\end{array}$ & $\begin{array}{c}\text { Loreng } \\
\text { Gurun Digital }\end{array}$ & $\begin{array}{c}\text { Loreng } \\
\text { Brimob }\end{array}$ \\
\hline Citra RGB & & \\
\hline Biner & & & \\
\hline
\end{tabular}

Tabel 6 Hasil Pengujian Data Berdasarkan Esktraksi Ciri Bentuk

\begin{tabular}{|c|c|c|c|c|c|c|}
\hline $\begin{array}{c}\text { Jenis } \\
\text { Data } \\
\text { Citra }\end{array}$ & $\begin{array}{c}\text { Loreng } \\
\text { Malvinas }\end{array}$ & $\begin{array}{c}\text { Loreng } \\
\text { Lain }\end{array}$ & $\begin{array}{c}\text { Error } \\
\text { Malvinas }\end{array}$ & $\begin{array}{c}\text { Error } \\
\text { Loreng } \\
\text { Lain }\end{array}$ & $\begin{array}{c}\text { Akurasi } \\
\text { Loreng } \\
\text { Malvinas }\end{array}$ & $\begin{array}{c}\text { Akurasi } \\
\text { Loreng } \\
\text { Lain }\end{array}$ \\
\hline $\begin{array}{c}\text { Malvinas } \\
\text { bentuk 1 }\end{array}$ & 20 & 35 & 2 & 2 & $90 \%$ & $94.2 \%$ \\
\hline $\begin{array}{c}\text { Malvinas } \\
\text { bentuk 2 }\end{array}$ & 20 & 35 & 4 & 4 & $80 \%$ & $88.5 \%$ \\
\hline $\begin{array}{c}\text { Malvinas } \\
\text { bentuk 3 }\end{array}$ & 20 & 35 & 2 & 1 & $90 \%$ & $97.1 \%$ \\
\hline $\begin{array}{c}\text { Malvinas } \\
\text { bentuk 4 }\end{array}$ & 20 & 35 & 2 & 4 & $90 \%$ & $88.5 \%$ \\
\hline Total & 80 & 140 & 10 & 11 & $87.5 \%$ & $92.1 \%$ \\
\hline
\end{tabular}

menghasilkan warna hitam sebagai background dan warna putih membentuk daerah-daerah yang akan dilakukan proses pengenalan pola/pencirian.

Setiap daerah yang terbentuk memiliki nilai eccentricity (perbandingan antara jarak foci ellips minor dengan foci ellips mayor dari suatu wilayah/bentuk pada objek) dan metric (perbandingan antara luas dengan keliling dari suatu wilayah/bentuk pada objek) yang akan menjadi dasar parameter untuk melakukan deteksi pada pakaian dinas lapang tentara nasional Indonesia (loreng Malvinas). Hasil pengujian data latih citra terdeskripsi pada tabel 4 .

Pengujian sistem dilakukan dengan menggunakan 115 data citra yang terdiri atas 20 data citra pola bentuk 1, 20 data citra pola bentuk 2, 20 data citra pola bentuk 3, 20 data citra pola bentuk 4, dan 35 data citra jenis loreng lain yang. Contoh data citra loreng lain terdeskripsi pada tabel 5. Semua data tersebut akan dilakukan pengujian dengan menggunakan algoritma yang telah dijelaskan sebelumnya. Hasil pengujian data terdeskripsi pada Tabel 6.

Dari 80 data citra yang dilakukan pengujian, terdapat 10 data citra yang memiliki kesalahan identifikasi (error) sehingga menghasilkan akurasi $87.5 \%$. Pengujian sistem juga dilakukan dengan menggunakan data citra loreng lain menghasilkan nilai akurasi $92.1 \%$. Dari 140 data citra, data error malvinas menunjukan data tidak dapat teridentifikasi atau data tidak sesuai dengan parameter data latih, sementara data error loreng lain menunjukan data terdeteksi sama dengan parameter data latih.

\section{Kesimpulan}

Pada paper ini diusulkan metode kombinasi Eccentricity dan Metric untuk mengenali jenis seragam loreng. Nilai eccentricity dan metric dari suatu objek tidak akan berubah walaupun posisi objek dilakukan perputaran sudut. Hasil pengujian menggunakan 80 data citra loreng "Malvinas" menghasilkan akurasi $87.5 \%$ Sedangkan pengujian menggunakan 140 data citra loreng lain menghasilkan akurasi 92.1\%. Hasil ini menunjukkan metode yang diusulkan kompetitif baik pada citra Loreng "Malvinas" maupun pada citra Loreng lain.

\section{Daftar Pustaka}

[1] Pfanner, T., "Military Uniform and The Law of War”, RICR Mars IRRC March Vol. 86, 2004.

[2] Irhebhude, M. E., Edirisinghe, E. A., "Personnel Recognition in The Military using Multiple Features", Loughborough University's Institutional Repository, 2015.

[3] Cooper, R. F., Wilk, M. A., Tarima, S., Carroll, J. "Evaluating Descriptive Metrics of the 
Human Cone Mosaic”, Investigative Ophthalmic and Visual Science Vol. 57, 2016.

[4] Gonzalez, R. C., Woods, R. E., "Digital Image Processing 3rd Edition", Addison-Wesley Publishing, 2007.

[5] Sutoyo, T., dkk., "Teori Pengolahan Citra Digital”, Yogyakarta: Penerbit Andi, 2009.

[6] Munir, R., "Pengolahan Citra Digital dengan Pendekatan Algoritmik", Bandung: Penerbit Informatika, 2004.

[7] Pierre, F., Aujol, J.F., Bugeau, A., Steidl, G., Ta, V.T, "Hue-Preserving Perceptual Contrast Enhancement", United States: Internationnal Conference on Image Processing, 2016.

[8] Balarini, J. P., Nesmachnow, S., "A $C++$ Implementation of Otsu's Image Segmentation Method", Image Processing on Line, 2016.

[9] Smith, S. W., "The Scientist and Engineer's Guide to Digital Signal Processing”, California: California Technical Publishing, 1997. 